\title{
Erythrocyte radiolabelling: in vitro comparison of chromium, technetium, and indium in undamaged and heat damaged cells
}

\author{
AM PETERS, ${ }^{*}$ S OSMAN,$\dagger$ HJ REAVY, $*$ B CHAMBERS,$\ddagger$ M DEENMAMODE $\ddagger$ \\ SM LEWIS $\ddagger$
}

\begin{abstract}
From the Departments of *Diagnostic Radiology, $\uparrow$ Radiochemistry, and $\ddagger$ Haematology, Royal Postgraduate Medical School, London
\end{abstract}

SUMMARY The stability of the commonly used red cell radio labels chromium-51, indium-(111 or $113 \mathrm{~m}$ ), and technetium-99m, within intact red cells and stroma and their distribution within the cell were compared in undamaged and heat damaged red cells in relation to the clinical use of heat damaged cells in the assessment of splenic function.

Chromium-51 labelled haemoglobin both in undamaged and heat damaged cells; indium predominantly labelled haemoglobin in undamaged cells but labelled stroma in heat damaged cells, even when the cells were labelled before heating; technetium-99m predominantly labelled haemoglobin in undamaged cells but only labelled stroma in heat damaged cells if these were heated before labelling. Indium was more firmly bound by stroma prepared from heat damaged cells, and technetium- $99 \mathrm{~m}$ showed a high rate of elution both from cells and stroma, although this rate was lower for heat damaged cells.

The rate of clearance from blood of radiolabelled heat damaged red cells is used as an index of splenic function. ${ }^{1-5}$ The kinetics of such clearance are complex, not only because of uptake at other sites in the body, ${ }^{26}$ but also because splenic uptake itself is the result of several kinetic processes. ${ }^{45}$ The stability of the radiolabel within the cells, the fragility of the cells, the stability of the label within fragments following disintegration of the cells, and the fate of such fragments, if labelled, all superimpose on the complexity of the overall clearance curve. With the ultimate aim of determining which of the commonly used isotopes chromium-51, indium-111 or indium-113m, and technetium-99m, used to label red cells, would be preferable for splenic function studies, we sought to determine the stability of these isotopes within heat damaged red cells, to identify their predominant site of deposition (cytosol or stroma), and to determine the stability within stroma of those isotopes deposited there.

\section{Material and methods}

Blood was obtained from normal subjects using acid citrate dextrose (ACD) (NIH-A) as anticoagulant. The red cells were isolated and washed in physiological saline.

Labelling was performed with chromium- $51,{ }^{7}$ technetium-99m, ${ }^{8}$ indium- $111,{ }^{9}$ or indium- $113 \mathrm{~m},{ }^{10}$ using published methods. For indium labelling acetylacetone $^{10}$ or tropolone ${ }^{11}$ was used as the ligand. Undamaged and heat damaged cells and stroma were studied. Damage was produced by heating $2 \mathrm{ml}$ packed cells in a glass bottle at $49 \cdot 5^{\circ} \mathrm{C}$ for 20 minutes. Stroma was prepared from heat damaged or undamaged cells by hypotonic lysis in excess distilled water, followed by centrifugation at $2000 \mathrm{~g}$ for 20 minutes. The percentage of activity bound to cells or stroma in suspension was determined by gamma counting (Packard, model 5360) activity in aliquots removed before and after centrifugation of the suspension at $2000 \mathrm{~g}$ for 20 minutes. Bound activity is then equal to the difference in counts divided by the precentrifugation count $(\times 100)$. The necessary correction for the haematocrit of the suspension was made only when it was $1 \%$ or more. 
In some experiments carbon tetrachloride was added to the lysed cells before centrifugation to generate separate aqueous and lipid phases. Activity previously present in the suspension that had not been bound to stroma was then recovered in the aqueous phase.

Several experimental procedures were adopted to determine: firstly, the distribution of each isotope within the red cell; secondly, the effect of heat damaging on this distribution; and thirdly, the stability of the label in cells--fragmented or intact.

\section{HEAT INDUCED LYSIS AND ELUTION}

Aliquots of $100 \mu \mathrm{l}$ were removed at 10 minute intervals from packed cells undergoing heat damage. They were transferred to volumes of $20 \mathrm{ml} 1 \cdot 2 \%$ saline at room temperature, and cell bound activity was measured. For the determination of cell lysis the haemoglobin concentration was measured in two $5 \mathrm{ml}$ aliquots of this suspension, one before and the other after centrifugation (Gallenkamp colourimeter 13). Cell bound haemoglobin was then calculated in the same way as that for the cell bound activity.

\section{LABELLING EFFICIENCY OF LABELLED LYSATES} Depending on the isotope, considerable activity was found in stroma. Because of the possibility that stroma becomes labelled after hypotonic lysis as a result of redistribution of isotope from cytosol, the ability of labelled particle free lysate to transfer its label to fresh stroma or cells was tested. Thus after hypotonic lysis of the labelled cells the lysate was separated from the stroma by centriguation and added to fresh cells or stroma.

DISTRIBUTION OF LABEL FOLLOWING LYSIS IN INCREASING WATER VOLUME

As a further examination of the above possibility hypotonic lysis was performed in volumes of water to give ratios of red cell volume to water volume of $10^{-1}, 10^{-2}, 10^{-3}$, and $10^{-4}$. Distribution of label between stroma and cytosol was then measured.

STABILITY OF LABEL

Labelled cells were resuspended in excess saline or autologous plasma. After 30 minutes and one hour aliquots were removed and the percentage cell bound activity (c) determined. Elution (k) was determined by least squares regression analysis based on the equation:

or

$$
\mathrm{C}=\mathrm{e}^{-\mathrm{Kt}}
$$

The percentage of activity that is cell bound at $t=0$, $\mathrm{C}(0)$, inversely reflects the quantity of isotope released from the cell on resuspension.

\section{ELUTION FROM STROMA}

Because technetium and indium label stroma, the re- 을 lease of these two isotopes on resuspension of stroma $\overrightarrow{\vec{F}}$ and the subsequent elution rate were determined, as described for intact cells. The percentage of remaining activity lost from the stroma with further centri- $\frac{\bar{c}}{\infty}$ fugation and resuspensions (washes) and the final $\overrightarrow{\widetilde{D}}$ activity left on the stroma after a total of two washes were also determined.

\section{ASSOCIATION OF HAEMOGLOBIN WITH \\ CYTOSKELETON}

To check the possibility that the change in distribution of isotope induced by heating is simply the result ? of increasing binding of haemoglobin to heat damaged stroma the association of haemoglobin with $v$ cytoskeleton in heat damaged $v$ undamaged cells was determined. Stromal associated haemoglobin was determined by comparing the haemoglobin concentrations in two identical hypotonically lysed red cell $\vec{c}$ suspensions, one before and the other after centrifugation.

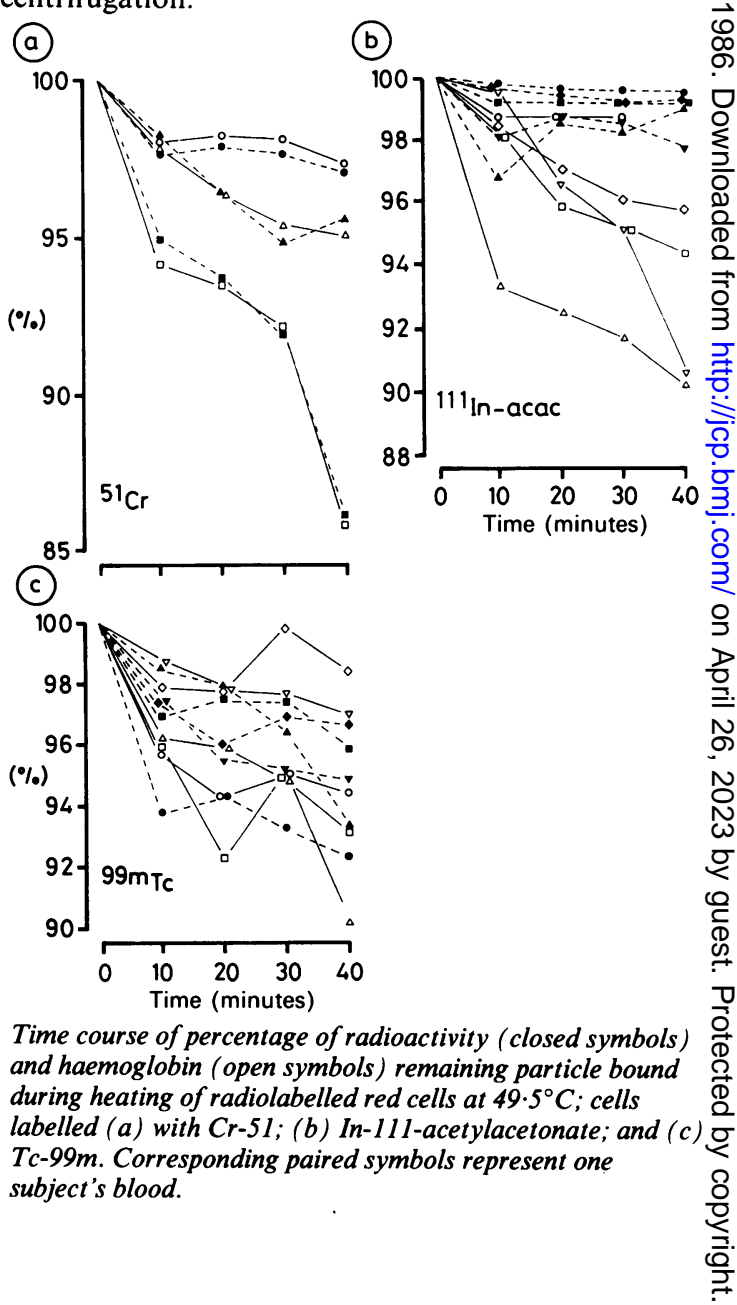


Table 1 Mean (SE) distribution of radiolabel between stroma and cytosol (a) after hypotonic lysis (percentage total activity bound to stroma); (b) after hypotonic lysis and carbon techloride extraction (total activity minus activity in aqueous phase (per cent))

\begin{tabular}{|c|c|c|c|c|c|c|}
\hline & \multirow{2}{*}{$\begin{array}{l}\text { Undamaged } \\
\text { Hypotonic lysis } \\
\text { (a) }\end{array}$} & \multirow{2}{*}{$\begin{array}{l}\text { Hypotonic lysis and carbon } \\
\text { techloride extraction } \\
\text { (h) }\end{array}$} & \multicolumn{2}{|c|}{$\begin{array}{l}\text { Heat damaged } \\
\text { Damaged, then labelled }\end{array}$} & \multicolumn{2}{|c|}{ Labelled, then damaged } \\
\hline & & & (a) & (b) & (a) & (b) \\
\hline $\begin{array}{l}\text { Chromium } \\
\text { Technetium } \\
\text { Indium (acetylacetone) } \\
\text { Indium (tropolone) }\end{array}$ & $\begin{array}{l}12(4) \\
16(10) \\
26(8) \\
24(11)\end{array}$ & $\begin{array}{r}7(2) \\
8(8) \\
20(4) \\
19(3)\end{array}$ & $\begin{array}{l}13(6) \\
65(11) \\
78(5) \\
73(8)\end{array}$ & $\begin{array}{l}10(3 \cdot 5) \\
73(6) \\
77(2) \\
75(2)\end{array}$ & $\begin{array}{l}8(5) \\
29(13) \\
75(5) \\
77(6)\end{array}$ & $\begin{array}{l}8(2 \cdot 5) \\
22(9) \\
73(4 \cdot 5) \\
75(6)\end{array}$ \\
\hline
\end{tabular}

Mean $\pm S E(n=6-8)$.

\section{Results}

\section{HEAT INDUCED ELUTION AND LYSIS}

The Figure shows the percentages of haemoglobin and radiolabel remaining cell bound at different times after heating for indium and chromium. With chromium it is evident that the free isotope liberated was equal to the free haemoglobin liberated. The same was essentially true for technetium, although the results were more variable. With indium, however, more free haemoglobin was liberated than isotope, indicating that most of the isotope remained in association with the stroma after heat induced lysis.

\section{DISTRIBUTION OF RADIOLABEL BETWEEN}

\section{STROMA AND CYTOSOL}

Distribution determined by hypotonic lysis and centrifugation was essentially the same as that recorded when the stroma was extracted into carbon tetrachloride before centrifugation (Table 1) and was in line with the distribution suggested by the heat induced elution results described above. With chromium about $90 \%$ of the label was in the cytosol, whether the lysed cells were previously undamaged or not. With technetium about $85 \%$ of the activity was found in the cytosol liberated from undamaged cells. If the cells were heat damaged, however, the distribution was different. Thus about $75 \%$ of the activity was in the cytosol when the cells were labelled before they were heated, or $30 \%$, if the cells were heated before being labelled. With indium about $80 \%$ of the activity was in the cytosol of undamaged cells, whereas only $25 \%$ was in the cytosol when the cells were damaged (irrespective of the order of heating and labelling and irrespective of the ligand used).

\section{EFFECT OF RED CELL:WATER VOLUME ON DISTRIBUTION}

Increasing the volume of water for hypotonic lysis had no appreciable effect on the subsequent distribution of radiolabel between stroma and cytosol (Table 2 ), suggesting that the stroma was not labelled as a result of uptake of isotope from solution immediately after lysis.

\section{LABELLING EFFICIENCY OF LABELLED LYSIS}

In line with the preceding observation, stroma free lysates, prepared from previously labelled cells, were unable to label fresh cells (after adjustment of osmolarity to physiological with hypertonic saline) or stroma (without adjustment of osmolarity), unless further ligand was added. Restoring the acetylacetone concentration in the lysate to $0 \cdot 19 \%$ gave a labelling efficiency of 48 ((SE) 5$) \%$, to $0.38 \%$, an efficiency of $54(2) \%$, and to $0.95 \%$, an efficiency of $64(0.6) \%$. No differences were detected between "undamaged" and "heat damaged" lysates, or between undamaged and heat damaged cells or stroma.

ASSOCIATION OF HAEMOGLOBIN WITH STROMA In undamaged cells $8(0.6) \%$ of the haemoglobin was associated with stroma in so far as it was sedimented

Table 2 Effect of ratio of labelled red cell:water (used for hypotonic lysis) volume on distribution of radiolabel between stroma and cytosol (values expressed as percentage of total activity bound to stroma after lysis)

\begin{tabular}{|c|c|c|c|c|}
\hline \multirow[t]{2}{*}{ Volume of cells ( $\mathrm{ml})$} & \multirow[t]{2}{*}{ Volume of water $(\mathrm{ml})$} & \multirow{2}{*}{$\begin{array}{l}\text { Indium } \\
\text { Undamaged }\end{array}$} & \multirow[b]{2}{*}{$\begin{array}{l}\text { Heat-damaged } \\
\text { (before labelling) }\end{array}$} & \multirow{2}{*}{$\begin{array}{l}\text { Technetium } \\
\begin{array}{l}\text { Heat-damaged } \\
\text { (before labelling) (mean SE) }\end{array}\end{array}$} \\
\hline & & & & \\
\hline $\begin{array}{l}0.1 \\
0.1 \\
0.1 \\
0.01\end{array}$ & $\begin{array}{r}1 \\
10 \\
100 \\
100\end{array}$ & $\begin{array}{l}22(n=2) \\
21(n=2) \\
25(n=2) \\
37(n=2)\end{array}$ & $\begin{array}{l}80(n=2) \\
79(n=2) \\
80(n=2) \\
81(n=2)\end{array}$ & $\begin{array}{l}52(4)(n=3) \\
57(n=2) \\
52(n=3) \\
48(0 \cdot 6)(n=3)\end{array}$ \\
\hline
\end{tabular}


Table 3 Loss of isotope from stroma, prepared from undamaged and heat damaged cells after resuspension of stroma in saline or plasma

\begin{tabular}{|c|c|c|c|c|}
\hline & \multicolumn{2}{|l|}{ Indium (mean $S E$ ) } & \multicolumn{2}{|c|}{ Technetium (mean SE) } \\
\hline & Saline & Plasma & Saline & Plasma \\
\hline $\begin{array}{l}\text { Undamaged: } \\
\text { First resuspension } \\
\text { Second resuspension } \\
\text { Third resuspension } \\
\text { Stroma }\end{array}$ & $\begin{array}{l}18(3)(n=11) \\
3 \cdot 3(1 \cdot 2)(n=8) \\
2 \cdot 6(1 \cdot 2)(n=7) \\
84(4)(n=8)\end{array}$ & $\begin{array}{l}42(5)(n=6) \\
10 \cdot 3(0 \cdot 5)(n=4) \\
12 \cdot 0(3)(n=4) \\
42(10)(n=4)\end{array}$ & $\begin{array}{l}44(8)(n=6) \\
35(8)(n=4) \\
20(4)(n=3) \\
18 \cdot 5(6)(n=4)\end{array}$ & $26(1 \cdot 5)(n=4)$ \\
\hline $\begin{array}{l}\text { Heat damaged (betore labeling): } \\
\text { First resuspension } \\
\text { Second resuspension } \\
\text { Third resuspension } \\
\text { Stroma }\end{array}$ & $\begin{array}{l}11(2 \cdot 4)(n=8) \\
2 \cdot 2(0 \cdot 7)(n=4) \\
2 \cdot 9(0 \cdot 6)(n=4) \\
92(2)(n=4)\end{array}$ & $10(2)(n=4)$ & $\begin{array}{l}8(2 \cdot 5)(n=4) \\
7 \cdot 6(n=2) \\
5 \cdot 6(n=2) \\
74(n=2)\end{array}$ & $7(2)(n=4)$ \\
\hline \multicolumn{5}{|c|}{ Results expressed as mean $\pm S E$ ( $n$ in brackets) } \\
\hline \multirow{2}{*}{ Table 4} & Stroma & & Cells & \\
\hline & Saline & Plasma & Saline & Plasma \\
\hline $\begin{array}{l}\text { Indium: } \\
\text { Undamaged } \\
\text { Heat damaged (before labelling) }\end{array}$ & $\begin{array}{l}3 \cdot 1(1 \cdot 5)(\mathrm{n}=11) \\
0 \cdot 8(1 \cdot 2)(\mathrm{n}=8)\end{array}$ & $\begin{array}{l}8.4(3)(n=6) \\
3 \cdot 6(1 \cdot 8)(n=4)\end{array}$ & & \\
\hline $\begin{array}{l}\text { Technetium: } \\
\text { Undamaged } \\
\text { Heat damaged (before labelling) }\end{array}$ & $\begin{array}{r}10 \cdot 6(3 \cdot 2)(n=4) \\
8 \cdot 3(2 \cdot 5)(n=5)\end{array}$ & $\begin{array}{c}12 \cdot 8(1)(n=3) \\
6 \cdot 2(1 \cdot 5)(n=4)\end{array}$ & $\begin{array}{l}4 \cdot 9(3)(n=5) \\
4 \cdot 7(1)(n=3)\end{array}$ & $\begin{array}{l}9 \cdot 4(n=2) \\
6 \cdot 3(n=2)\end{array}$ \\
\hline
\end{tabular}

The loss of activity from indium and chromium labelled cells (undamaged and heat damaged (before labelling)) was negligible at less thano $1 \% /$ hour.

by centrifugation after hypotonic lysis. The corresponding value for heat damaged cells was similar at $8 \cdot 3(0 \cdot 3) \%$.

\section{LOSS OF ACTIVITY ON WASHING OF STROMA OR} CELLS AND ELUTION RATE

Tables 3 and 4 summarise the percentages of activity liberated into the medium after washing of stroma (labelled with indium and technetium) and the elution rates of activity from such stroma and from labelled intact cells.

Chromium and indium remained firmly bound to intact cells, both undamaged and heat damaged, whereas technetium eluted at $5 \%-10 \%$ per hour. The activity (technetium and indium) on undamaged stroma was less firmly bound than that on heat damaged stroma, detaching more readily on washing and eluting more rapidly. Activity was also more readily removed from stroma when the medium was plasma rather than physiological saline.

The labelled undamaged or heat damaged cells were lysed in water, the stroma pelletted, and the lysate removed. The labelled stroma was resuspended in saline or plasma. The values shown in Table 3 under first resuspension were the percentages of the total activity in the suspension not bound to the stromathat is, the percentage activity released on the first resuspension. The stroma was pelletted again and resuspended in more saline or plasma and this time the values shown (Table 3) were the percentages of remaining activity not bound to stroma after this $\sec \sum$ ond and third suspension - that is, the percentage activity released with each resuspension. "Stroma' indicates the percentage of the initial activity stil $\mathbb{R}$ bound to stroma after the successive washes.

\section{Discussion}

In this study we found that chromium binds to com ponents in the cytosol of the red cells. Others ${ }^{12}$ have described the binding site as the globin moeity of hae-을 moglobin, and our results are consistent with this Technetium is also thought to bind predominantly tog globin, ${ }^{1314}$ and our results were also consistent with this, with regard to undamaged cells. With respect to heat damaged cells, however, the distribution seemed to be different, with much more activity present in the stroma. Indium has previously been reported to bind to both haemoglobin and stroma. ${ }^{15}$ Again, our' results were consistent with this finding.

Although Rao and Dewanjee ${ }^{15}$ found only about $40 \%$ of the activity in the haemolysate of undamaged cells labelled with indium tropolonate, they, like us found about $75 \%$ in the haemolysate from cells labelled with indium acetylacetonate, at a concentration similar to that used in our study. When cells were heat damaged, however, we found a quite different? distribution, with only about $25 \%$ in the cytosol. Interestingly, this distribution seemed to be unaffected not only by the ligand used (acetylacetone or tro- 
polone), but also by the order in which the cells were labelled and heated. This curious finding suggested a possible artefact in that such a distribution may not have been present before lysis but may have been the result of an avid uptake of free isotope (still complexed with lipid soluble ligand) by the stroma from the lysate after lysis. This possibility was, however, excluded by showing that labelled lysates were unable to label fresh cells or stroma and by finding that the relative volumes of cells and water (used for lysis) had no effect on apparent distribution. The transfer of label from cytosol to stroma induced by heating could not be explained by the fixation of labelled haemoglobin to stroma as the amount of haemoglobin associated with stroma was not increased after heat damaging.

As an appreciable fraction of indium and, in the case of heat damaged cells, technetium, was associated with stroma, it seemed worthwhile to evaluate the stability with which these isotopes labelled stroma. Indium was very firmly bound, particularly to stroma from heat damaged cells, when evaluated as an elution rate or as activity released on washing. Activity detached from stroma more readily in plasma than in saline, reflecting the avidity of indium for transferrin. Technetium was also more firmly bound by heat damaged than by undamaged stroma, as reflected by stability during washing, although as most of the activity in the undamaged cell is in the cytosol, the activity apparently released on the first resuspension of stroma may be overestimated.

Given that the heat damaged red cell clearance curve is corrected for plasma bound activity, the fate of stroma determines the relevance of stromal binding. About $90 \%$ of stroma is cleared by the liver, ${ }^{16}$ almost certainly much more rapidly than splenic clearance of intact heat damaged cells. When there is lysis in the preparation before injection, the clearance of indium labelled heat damaged cells would, in addition to splenic uptake, contain a component of liver stromal uptake, a negligible component, however, due to elution. Technetium labelled cell clearance should also contain a component resulting from elution. The clearance of chromium labelled cells, on the other hand, would be predicted to be free of components, both of stromal uptake and elution. Any lysis occurring in vivo would be registered as intact cell clearance, although this would be common to all three labels. This implies that chromium is the best label, notwithstanding its poorer counting statistics. On the other hand, the washing of technetium or indium labelled heat damaged cells in isotonic rather than hypertonic saline, and the use of minimal centrifugation speeds before injection decreases the component due to liver uptake after injection, ${ }^{5}$ pre- sumably as a result of the inclusion of less labelled stroma. Using this approach, indium should then be as good as chromium.

We are grateful to Dr HJ Danpure and Professor JP Lavender for helpful advice and to Miss Sally Barnes for secretarial help. HJR was financially supported by the Nuffield Foundation.

\section{References}

${ }^{1}$ Pettit JE. Spleen function. Clin Haematol 1977;6:639-56.

${ }^{2}$ Lockwood CM. Worlledge S. Nicholas A. Cotton C. Peters DK. Reversal of impaired splenic function in patients with nephritis or vasculitis (or both) by plasma exchange. $N$ Engl J Med 1979;300:524-30.

${ }^{3}$ Williams BD, Pussell BA, Lockwood CM. Cotton C. Defective reticuloendothelial system function in rheumatoid arthritis. Lancet 1979;i:1311-14.

${ }^{4}$ Peters AM, Ryan PFJ, Klonizakis I. Elkon KB, et al. Kinetics of heat damaged autologous red blood cells. Mechanism of clearance from blood. Scand J Haematol 1982:28:5-14.

5 Peters AM, Walport MJ. Elkon KB, et al. The comparative blood clearance kinetics of modified radiolabelled erythrocytes. Clin Sci 1984;66:55-62.

${ }^{6}$ Peters AM, Klonizakis I, Lavender JP. Lewis SM. Elution of 111 indium from reticuloendothelial cells. J Clin Pathol-1982; 35:507-9.

${ }^{7}$ Marsh GW. Lewis SM, Szur L. The use of chromium-51-labelled heat-damaged red cells to study splenic function. I. Evaluation of method. Br J Haematol 1966;12:161-6.

${ }^{8}$ Jones J, Mollison PL. A simple and efficient method of labelling red cells with technetium-99m for determination of red cell volume. Br J Haematol 1978:38:141-8.

${ }^{9}$ McAfee JG. Thakur ML. Survey of radioactive agents for in-vitro labelling of phagocytic leukocytes. I. Soluble agents. Journal of Nuclear Medicine 1976:17:480-7.

${ }^{10}$ Radia R. Peters AM. Deenmamode M, Fitzpatrick ML. Lewis SM. Measurement of red cell volume and splenic red cell pool using ${ }^{113 \mathrm{~m}}$ indium. Br J Haematol 1981;49:587-91.

${ }^{11}$ Danpure HJ, Osman S. Brady F. The labelling of blood cells in plasma with In-tropolonate. Br J Haematol 1982;55:247-9.

${ }^{12}$ Gray SJ, Sterling K. The tagging of red cells and plasma proteins with radioactive chromium. J Clin Invest 1950;29:1604-13.

${ }^{13}$ Dewanjee MK. Binding of ${ }^{99 \mathrm{~m}} \mathrm{Tc}$ ion to hemoglobin. Journal of Nuclear Medicine 1974:15:703-6.

${ }^{14}$ Thompson S, Newman P, Maddy AH. An examination of the labelling of intact human erythrocytes with ${ }^{99}$ technetium. $B r J$ Haematol 1981:49:575-80.

${ }^{15}$ Rao SA. Dewanjee MK. Comparative evaluation of red celllabelling parameters of three lipid-soluble ${ }^{11}$ Inchelates: effect of lipid solubility on membrane incorporation and stability constant on transchelation. European J Nucl Med 1982:7:282-5.

${ }^{16}$ Schulman NR, Weinrach RS, Libre EP. Andrews HL. The reticuloendothelial system in the pathogenesis of idiopathic thrombocytopenic purpura. Trans Assoc Am Physicians 1965;78: $374-90$.

Requests for reprints to: Dr AM Peters, Radioisotope Scanning Unit, Hammersmith Hospital, Du Cane Road, London W12 0HS, England. 